\title{
Investigation of Corrosion Inhibition Efficiency of Amazonian Tree Alkaloids Extract for C38 steel in 1M Hydrochloric Media
}

\author{
Maxime Chevalier ${ }^{1, *}$, Mounim Lebrini ${ }^{1,}$, , Florent Robert ${ }^{l}$, Sylvain Sutour ${ }^{2}$, Felix Tomi $^{2}$, Charafeddine \\ Jama $^{3}$, Fouad Bentiss ${ }^{3,4}$ and Christophe Roos ${ }^{1, *}$ \\ ${ }^{1}$ Laboratoire Matériaux et Molécules en Milieux Agressifs, UA - UMR ECOFOG Campus de \\ Schœlcher, 97233 Schœlcher, France \\ 2 Laboratoire Science Pour 1'Environnement, Equipe Chimie et Biomasse, URA CNRS 2053, \\ Université de Corse, Route des Sanguinaires, 20000-Ajaccio, France \\ 3 Laboratoire UMET-PSI, CNRS UMR 8207, ENSCL, Université Lille I, CS 90108, F-59652 \\ Villeneuve d'Ascq Cedex, France \\ 4 Laboratoire de Catalyse et de Corrosion des Matériaux (LCCM), Faculté des Sciences, \\ Université Chouaib Doukkali, B.P. 20, M-24000 El Jadida, Morocco \\ *E-mail: maxime.chevalier@univ-antilles.fr, mounim.lebrini@univ-antilles.fr, \\ christophe.roos@martinique.univ-ag.fr
}

doi: $10.20964 / 2019.02 .38$

Received: 27 April 2018 / Accepted: 21 November 2018 / Published: 5 January 2019

The present study investigated the potential of the alkaloidic extract of Xylopia cayennensis used as C38 steel corrosion inhibitor in $1 \mathrm{M} \mathrm{HCl}$ by electrochemical impedance spectroscopy and potentiodynamic polarization. Both methods indicated that Xylopia cayennensis alkaloidic extract (XCAE) acts as mixed-inhibitor with maximal efficiency up to 93\% (polarization curve) and 94\% (EIS measurements) for $200 \mathrm{mg} / \mathrm{L}$. The effect of time immersion and temperature was discussed, as well as adsorption mechanism (with XPS study and adsorption isotherm). Phytochemical study was undertaken to highlight key compound responsible for the corrosion inhibition and determine major constituent of this extract, and to permit better comprehension of adsorption mechanism.

Keywords: C38 steel; Xylopia cayennensis extract; Adsorption-XPS; Acidic media; Corrosion inhibitor.

\section{$\underline{\text { FULL TEXT }}$}

(C) 2019 The Authors. Published by ESG (www.electrochemsci.org). This article is an open access article distributed under the terms and conditions of the Creative Commons Attribution license (http://creativecommons.org/licenses/by/4.0/). 